\title{
Revenue Administration in the Philippines: Significant Collection Reforms, TRAIN Law, Fiscal Incentives, Excise Tax, and Rice Tariffication Law
}

\author{
Mark M. Alipio a,b \\ April 2020 \\ ${ }^{a}$ Davao Doctors College, General Malvar St., Davao City 8000, Philippines \\ ${ }^{b}$ University of Southeastern Philippines, Mintal, Davao City 8000, Philippines
}

\begin{abstract}
This paper argues the present revenue administration of President Duterte in the Philippines. Significant collection reforms, TRAIN law, fiscal incentives, excise tax, and rice tariffication law were especially discussed in this paper to provide a lens of the current revenue restructuring and an improvement plan for the country's economy.
\end{abstract}

Keywords: Collection Reforms, Economy, Excise Tax, Fiscal Incentives, Government, Philippines, Revenue Administration, Rice Tariffication Law, TRAIN Law

\section{Significant Collection Reforms under the Duterte Administration}

\section{'TRABAHO'-mandatory electronic invoicing and sales reporting}

Tax Reform for Attracting Better and Higher Quality Opportunities or 'TRABAHO', a TRAIN Law Package 2, aids the Bureau of Internal Revenue (BIR) in going after tax evaders, and more importantly, modernizing the revenue collection agency. TRABAHO implements provisions that authorize electronic record keeping for receipts and sales reports, filing via electronic channels, and implementation of electronic sales reporting. These modernization measures ensure that taxpayers will find it easier to file and pay their taxes. Simply put, the taxpayers are required to use a system that is capable of issuing electronic receipts or invoices, collecting transaction records and transmitting these records to the BIR. The premise is that this system will simplify and speed up not only business transactions but the tax administration procedures of the government as well. Essentially, in an electronic invoicing and sales reporting system, both the issuer and the recipient of the invoice can access and review the invoices generated. On the other hand, tax authorities are able to collect and analyze the electronically transmitted data in real time. 
I find modernization of the BIR through electronic filing, electronic sales reporting, acceptance of electronic receipts and most importantly, through electronic channels relevant and effective. More electronic channels would mean that taxpayers would be able to choose which channel and method of payment will be most convenient with them.

\section{Mandatory fuel marking}

The mandatory fuel marking system under the TRAIN law is expected to curb the about P26.9 billion to P43.8 billion loss in government revenues due to oil smuggling. The fuel marking, strategically designed by the combined team of the Department of Finance, BOC and BIR, is required on all petroleum products that are refined, manufactured, or imported into the Philippines that are subject to the payment of duties and taxes such as but not limited to gasoline, denatured alcohol used for motive power, kerosene, and diesel fuel oil after the taxes and duties have been paid. Marked fuel will indicate that batches have paid the required tariffs and went through all the necessary steps before it is sold in the market.

I find mandatory fuel marking relevant and effective to prevent fuel fraud and smuggling due to unequal tax rates imposed on different kinds of fuels. It is intended to monitor the correct payment of taxes and prevent revenue loss arising from illicit transfer of fuel. It is effective for the following reasons: it would tax receipts and sales revenue from increased volumes of official fuel in legal circulation, it would enhance control to improve tax compliance and reduce tax evasion, it would ensure that government bodies and regulators are able to collect the appropriate amount of revenue from excise taxes on fuel and it would prevent the illegal import of no or low-tax products and the dumping of transit, export or subsidized fuels.

\section{Expanded Large Taxpayers Base of BIR}

The Bureau of Internal Revenue Large Taxpayer Service (BIR-LTS) has identified some 200 corporations and institutions as large taxpayers in Mindanao. Instead of going to Cebu, these large taxpayers will be catered by the Mindanao BIR-LTS in Davao City.

Large Taxpayers Service (LTS) of the Bureau of Internal Revenue (BIR) serves as a one-stop shop for the country's so-called taxpayers. Initially, there were 1,000 selected taxpayers based on the criteria relating to the amount of taxes paid or payable set. BIR is seeking to expand its registry of large taxpayers from 2,320 to 3,000 to improve the agency's tax collection effort and increase government revenue.

I think the expanded LTS would be effective to help BIR meets its target collection. The launching of BIRLTS office in Davao City would be convenient for the transactions, payments, and any other related services that can be prescribe for the large taxpayers in Mindanao.

\section{Paperless Transactions at Port of Manila}

The CARGO clearance process at the Port of Manila will now be fully paperless. BOC ordered the removal of the Formal Entry Division's 15 window sections as part of efforts to curb corruption. Import entry declarations are made through that unit, but the face-to-face transactions between Customs examiners and traders could prompt collusion in declaring valuation of shipments that favor the importer in exchange for money. 
I think paperless transactions is relevant as this will adapt new technologies to do away with face-to-face contact and more familiarity. However, even if you remove the person to person contact, examiners and traders can still meet outside and collude. Some argued that the only issue to curb misevaluation is by putting an effective and up-to-date reference value of commodities.

\section{Reduction of Personal Income Tax}

Tax is considered as the bloodline of the national expenditures which means to say, that without this proportional contribution, the system of the government will become paralyzed and the programs and projects on the development of the country will not continue. It is sought that in the old tax system, those earning below $\mathrm{P} 250,000$ have to pay taxes. But the in the new tax system, those earning below $\mathrm{P} 250,000$ are tax exempt.

I see that the new tax system became more proportionate and realistic especially for those low-income earners as they given a full opportunity and security in maximizing their income to suffice their needs without slash. Those who earn more must spend more for the government because they have the capacity to extend their maintenance for the government. On the other hand, I don't think there is a problem on the increase on taxes in sweetened products and cigarettes, why because one of the duties of the government is to promote healthy lifestyle to the people. The government cannot spend more for those patients diagnose diabetes, lung cancer and other diseases. There is always a substitute for everything, instead we drink soft drinks, we can sustain ourselves to drink water. You must look into more side where we can benefit than to the side of our loss. I think this collection reform is effective, significant and important.

\section{TRAIN Law: A Reflection of Taxation Principles}

There are three principles of taxation, namely Fiscal Adequacy, Theoretical Justice and Administrative Feasibility. Fiscal adequacy means the sources of revenue must be sufficient to meet government expenditures and other public needs. Administrative feasibility means tax laws and regulations must be capable of being effectively enforced with the least inconvenience to the taxpayer. And theoretical justice means that a sound tax system must be based on the taxpayers' ability to pay.

The vision of the TRAIN Law is that by 2022, the tax reform aims to achieve the following: 1) poverty rate is reduced from $22 \%$ to $14 \%$ (uplifting some six million Filipinos from poverty); 2) the Philippines will become a law abiding country; 3 ) there will be peace within the country and with our neighbors; and, 4) to graduate to upper middle-income country status from the current low middle-income country status.

The TRAIN Law addresses several weaknesses of the tax system by lowering and simplifying personal income taxes, simplifying estate and donor's taxes, expanding the value-added tax base, adjusting oil and automobile excise taxes, and introducing excise tax on sugar-sweetened beverages.

The TRAIN Law is over a year old, and government finance experts are crediting it for robust profits and higher sales. Government sources asserted that double-digit growth in sales and high profit margins of premier retail and real estate companies in the Philippines are indicators that the implementation of the TRAIN Law is a success. 
I agree that the TRAIN Law has put more money in the pockets of the consumers and ensured strong domestic demand in the economy. The revenue measure also raised much-needed additional funds for the government's extensive spending on its build, build, build program and on human capital development.

There is high percentage of individual taxpayers that enjoy reductions in their personal income tax rates. Also, the significant growth in sales and income of corporate giants in the real estate and fast-food industries are strong indicators that Filipinos had started to benefit from the TRAIN Law by way of their purchasing power.

I think in general; the TRAIN Law has promoted the principle of sound taxation. Most people are happy with increased take home pay, the government's revenue collections are on target, and the inflation has remained manageable.

The government should continue to monitor its implementation and make sure that the fruits of TRAIN are going to be well-spent, otherwise, the TRAIN will be derailed.

\section{On fiscal adequacy}

In this principle, sources of revenue should be sufficient to meet the demands of public expenditure and revenues should be elastic or capable of expanding or contracting annually in response to variations in public expenditure. I believe that the TRAIN law promotes fiscal adequacy since one of the key features of the tax reform system is ensuring adequate revenues. Adequate government revenues are critical for a country's development, and improving infrastructure, reducing poverty and inequality, and investing in health and education - all require strong public finances. The Asian Development Bank estimates that the Philippines will need to invest about 7\% of GDP annually in infrastructure alone to support the country's rapid growth. The Duterte administration is targeting reaching that level of infrastructure investment by 2022 through TRAIN law, more than doubling it from less than 3\% of GDP on average over the past two decades. The tax reform and improvements in tax administration aim to raise up to 3\% of GDP annually in additional revenues, with $70 \%$ of this earmarked for infrastructure and $30 \%$ for social spending.

\section{On theoretical justice}

This principle mandates that taxes must be just, reasonable and fair. Taxation shall be uniform and equitable. I believe that the TRAIN law promotes theoretical justice as the tax system supports vertical and horizontal equities. Vertical equity refers to how the tax system treats people with different incomes. Most tax systems aim for progressivity, where the rich pay a higher share of their income in taxes than the poor. The first phase of the tax reforms addressed this issue and succeeded in reducing personal income taxes for the bottom $99 \%$ of the population. Horizontal equity refers to how the tax system treats similar entities. This ensures fairness that the playing field must be level, so that similar entities face similar tax rates. If the current system is looked at, the incentives that some firms get but others don't work against horizontal equity. Firms that manage to get tax incentives face much lower effective tax rates of 6-14\%, whereas firms that don't face a $30 \%$ rate. TRAIN law aims to improve horizontal equity by rationalizing fiscal incentives for businesses. 


\section{On administrative feasibility}

This principle states that the tax law must be capable of effective or efficient enforcement. Laws should be capable of convenient, just and effective administration. In addition, tax laws should close-up the loopholes for tax evasion and deter unscrupulous officials from committing fraud. The TRAIN law promotes administrative feasibility since it reflects two features of sound tax system - simplicity and transparency. TRAIN law aims to help by replacing the 123 special laws that govern tax incentives with a single law, and bring the 14 different investment promotion agencies under a single body, the Fiscal Incentives Review Board. One lesson from history is that the government should not be in the job of "picking winners" — the track record of countries around the world in doing this is not good, and it often stimulates lobbying for personal gain. Rather, incentives should be based on firms' documented ability to deliver, whether it be creating more jobs, raising incomes, or increasing exports. The Tax Incentives Management and Transparency Act is possible to analyze whether tax incentives - which reduced government revenues by P301 billion in 2015 have delivered the employment, income, and export growth it promised. This lines up well with the objective of TRAIN law to make tax incentives more performance-based.

\section{Correcting Market Failures through Fiscal Incentives}

To attract foreign and domestic investors into the country, the government usually offers various tax incentives with the primary objective of encouraging investments in desirable areas of activities through the adoption of a of a cohesive and consolidated investments incentives law. It also aims to develop the country's industries by establishing and promoting a competitive investment environment and at the same time discourage monopolies (Guide to Philippine Taxes)

The advantages of foreign direct investment (FDI) to host countries, particularly in terms of economic growth, have long been recognized. Foreign direct investment not only provides direct capital financing, but also provides technology and know-how, and promotes linkages between firms in a certain locality. In this sense, it can provide a boost to an economy, which tends to explain why countries provide both fiscal and non-fiscal incentives to attract foreign investments (Alfaro, 2013).

According to the Department of Finance (DOF) data, the Philippines currently imposes a corporate income tax (CIT) rate of $30 \%$ but with a tax collection efficiency of only 12.3 percent, while Thailand's CIT rate is only 20 percent but it collects almost triple-a 30.5 percent efficiency rate that represents 6.1 percent of its GDP.

Vietnam's CIT rate is 25 percent but it collects even more with a 29.2 percent tax efficiency rate representing 7.3 percent of GDP. Malaysia's 24 percent CIT generates a 27.1 percent efficiency rate in terms of collecting taxes, which is 6.5 percent of GDP.

DOF asserted that the flawed and outdated system that provides tax incentives to companies under 150 investment laws and 210 non-investment laws is the reason for the country's low CIT collection efficiency. The DOF plans to lower the CIT rate to 25 percent, while rationalizing incentives for companies to make these performance-based, targeted, time-bound, and transparent. 
I think fiscal incentives will not automatically translate to increase of foreign direct investment. Tax incentives for investment are often provided in response to what neighbouring countries and competitors are offering or perceived to be offering.

Sometimes, incentive schemes are overgenerous or poorly designed that they can result in giving money away without affecting investment. Even worse, incentives can be captured by politically connected firms and used for diverting public funds into political finance.

Sometimes, tax incentives do not make a difference in factoring out cash flow analysis by prospective investors. There are other serious non-fiscal matters that are considered by investors. Tax incentives are most likely to be ineffective in the face of an unattractive investment environment.

Philippines electricity rates is still highest in Southeast Asia. Metro Manila has 3rd worst traffic in Southeast Asia. These, and the general perception of our country's risk raises the investor's hurdle rate for investment. On the corruption perception index for Southeast Asia, the Philippines is perceived to be more corrupt and rank higher compared to neighbouring Vietnam, Indonesia, Thailand, Malaysia, Brunei and Singapore.

Albeit, the Philippines democratic accountability is improving and there is political desire and promise of transparency, foreign direct investment inflows in the Philippines still lag in Southeast Asia.

Fiscal incentives could address market failures as there is steady increase in FDI inflows, however, reforms for strong democratic accountability, attractive investment environment, and more transparency of tax expenditures should be instituted.

\section{Excise Tax Imposition on Fuel}

The government sees that the imposition of tax on petroleum products is being characterized as an antiinflation measure. The Duterte's Administration is on their way in addressing issues on the environment because the emission on carbon that causes unstable global sustainable future.

The reason why excise tax is imposed on fuel because fuel itself is a good source of income and collection for the government which according to the Department of Finance, not been adjusted by the year 1997 . Filipino household consumes a lot of fuel in their homes especially on transport services where fuel is essential. Under the Tax Reform for Acceleration and Inclusion law, the government has imposed a P7 per liter tax on diesel, cooking gase, kerosene and bunker fuel as well as higher taxes on gasoline staggered over three years. The TRAIN Law imposed a new tax of P2.50 per liter or kilogram on diesel, cooking gas, kerosene and bunker oil for electricity generation and raised the excise tax on gasoline to P7 from P4.35 per liter in 2018. On the other hand, the higher taxes on fuel may affect the connection and personality of our transport industry. On the part of the government and revenue agencies, it will be always beneficial to them because the increase of taxes would also lead to higher collection but these transport group would also demand for an increase on fare, on the side of our jeepney driver's and operators. There will be an inflationary domino impact to this scenario. 


\section{Rice Tariffication Law Safety Nets}

Republic 11203 or also known as the Rice Tariffication Law signed by President Rodrigo Duterte on 14th Day of February, 2019 which open doors to rice importation regulated by the government that will lead to the food staple more affordable for the Filipinos. The law seeks to amend Republic Act (RA) No. 8178 or the Agricultural Tariffication Act of 1996 and replace the quantitative restriction (QR) on rice imports. Instead of limiting how much rice will enter the country, rice imports will just be slapped with a tariff.

My recommendation on safety nets to the rice tariffication law: Safety net is defined as a safeguard against hardship or adversity. Safety net lifts people out of poverty during times of high unemployment and slow economic growth.

There is skepticism over the future of the local rice industry following the enactment of the rice tariffication law. They fear that local rice industry does not stand a chance with massive rice imports. The farmers will bear the brunt of the influx of imported rice.

The Philippine government will provides key interventions to support farmers and enhance their competitiveness and profitability, including farm machinery and equipment to improve farm operations, rice seed development, propagation, and promotion, expanded rice credit, and extension services. A portion of the rice tariff revenues will be used to provide direct financial assistance to rice farmers.

The key challenge is how to attain rice self-sufficiency and food security to adequately feed a growing population, and how to raise rice productivity and making the Filipino farmers profitable, globally competitive and climate-resilient.

Safety nets should include programs to address the lack of basic skills in farming; addressing high cost of fertilizers, pesticides and seeds; programs for Integrated Rice-Livestock/Fishery \& Multi-cropping systems; programs for Diversified Farming Technologies; and strengthening of Agricultural Cooperatives.

Agriculture is dying in the Philippines. Most of our farmers do not own the land they till. And since they are just tenants, some landowners require 50-50 share of the product. Farmers represent the second poorest sector in the country. The average age of Filipino farmers is 57-59 years old and their succeeding generations are likely to choose to be OFWs or shifting into other careers.

The Philippine government should incentivize young people to pursue a career in agriculture. There is a great need to encourage the youth to engage in crop production to ensure the country's food security. The Agricultural Training Institute should offer relevant courses for basic skills in farming and encourage young men and women to take Agripreneurship. Technical courses in Agriculture should build capabilities and offer career and business opportunities to make it attractive to the youths.

Farmers should belong to cooperatives. Co-ops power our sustainable farmers. Agricultural cooperative is a form of farmer collective action for the marketing and processing of farm products and or for the purchase $\&$ production of farm inputs. They aim to increase members production and incomes by helping better link them with finance, agricultural inputs, information, and output markets. 


\section{References}

Nasir, A., Noordin, M., Farheeza, D., \& Nordin, M. (2011). Technical skills and non-technical skills: predefinition concept. Proceedings of the IETEC'11 Conference, Kuala Lumpur, Malaysia.

Alipio, M. M. (2020). Chest Radiographic Findings of Patients Infected with 2019-nCOV. Chest.

Alipio, M. M. (2020). Predicting Academic Performance of College Freshmen in the Philippines using Psychological Variables and Expectancy-Value Beliefs to Outcomes-Based Education: A Path Analysis.

Alipio, M. M. (2020). Challenges and Strategies for Curbing the 2019-nCOV Pandemic: The Case of the Philippines.

Alipio, M. M. (2020). 2019-nCOV Scare: Situation Report, Role of Healthcare Professionals and Clinical Findings.

Alipio, M. M. (2020). Academic Adjustment and Performance among Filipino Freshmen College Students in the Health Sciences: Does Senior High School Strand Matter? 